\section{Germany to shift funding from physics to biology}

Munich. After a decade of generous support of large-scale physics programmes, the German Ministry of Research (Bundesministerium für Forschung und Technologie, BMFT) has decided to direct more of its funds into centres of excellence in the biological sciences. The change will relegate to a lower priority such new large items of equipment as accelerators.

The BMFT has adopted in principle the newly published recommendations of its advisory committee, chaired by physicist Siegfried Grossmann. In addition to a restructuring of Germany's research base, the committee has also suggested that industry should put more money into basic research, in particular such areas as chemistry.

The Grossmann committee was created in July 1990 by Germany's research minister, Heinz Riesenhuber, to analyse the balance of BMFT research spending and to recommend changes in line with Europe's new political map. Germany's spending on research, at 2.9 per cent of the country's gross national product, is already one of the highest in the world. About a fifth of that is spent on basic research. But the unexpectedly high cost of reunification, as well as a creeping increase in the proportion of BMFT funding directed to basic research (from 26 per cent in 1982 to 40 per cent in 1990) has forced a rethinking of the country's research priorities.

The Grossmann report stresses the need for a greater commitment to the life sciences. At present, only 14.5 per cent of the BMFT budget is invested in biomedical research, including biotechnology. Committee member Horst Kern, professor of cell biology at the University of Marberg, says that the United States carries out about 80 per cent of the world's important molecular

\section{Allocation of the 1990 BMFT budget for basic research (total is DM3,170 million).}

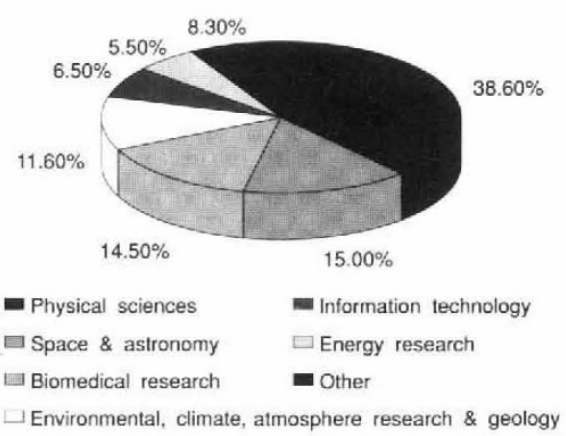

biology research. A greater, long-term commitment to biomedical research that exploits new biological technologies would help strengthen the German economy, he says.

The report proposes new centres to specialize in genetics and neurobiology. They would be analogous to the National Cancer Centre in Heidelberg, the ministry's major recipient of biomedical research funding and renowned for its work establishing a link between papillomavirus and cancer of the cervix. It also recommends greater support for existing groups at universities and research institutes working in such areas as AIDS and infectious diseases. Harald zur Hausen, director of the Heidelberg centre, says that the absolute level of biology funding has long been too low. He hopes that tight budgets will not prevent the ministry from carrying out the recommendations of the Grossmann report.

Despite the new emphasis on the life sciences, Riesenhuber says that large current projects in the physical sciences are unlikely to be curtailed. But requests for expensive equipment, he says, are more likely to be turned down. Speaking for the BMFT, Christian Uhlhorn says that the ministry believes that it is now time to assimilate data from its investment of billions of marks on large-scale equipment research in the physical sciences rather than replace machinery with newer models. Such a policy, for example, could limit Germany's contribution to the proposed Large Hadron Collider at CERN, the European Laboratory for Particle Physics in Geneva.

Final decisions about the fate of various physics projects await the announcement in July of the 1993 BMFT budget. The new budget is expected to increase the ministry's current allocation of DM9,200 million (US $\$ 5,000$ million) by only the rate of inflation - an amount unlikely to be enough to cover the research demands of a unified Germany.

Alison Abbott

\title{
Germany seeks new funds to meet costs
}

Munich. Germany's science research council wants to abandon its promise to accept an annual increase of only 5 per cent in its funding because it needs more money to cope with a sharp rise in grant applications and a new wage settlement of 5.4 per cent with public-sector unions.

An agreement was reached in 1990 between the government and the Deutsche Forschungsgemeinschaft (DFG) that would limit growth in the research council's funding to 5 per cent a year for five years. But the DFG president, Wolfgang Fruhwald, announced in January that the so-called 'fivetimes-five' agreement was no longer tenable. Grant applications had been increasing at an unprecedented level - around 9 per cent a year since 1989 - and, for the first time, applications with high priority ratings were not being funded.

About 75 per cent of the DFG budget is spent on salaries. As most DFG employees work in the public sector, this year's budget increase of 5 per cent will be wiped out by the recent wage agreement.

Frubwald is pressing for an 8.5 per cent rise in 1993, but DFG says that even that level would be insufficient to cover its basic funding needs. "Twelve per cent would be more realistic", says Eva-Maria Streier, speaking on behalf of the council. Its decision to seek a smaller amount, she says, was intended as a gesture of goodwill.

There are several reasons for the rise in applications, which last year exceeded 10,000. Part of the cause is reunification, although a special fund of DM90 million
(US\$50 million) was created in 1991 to finance more than 1,000 grants for the states in eastern Germany. In addition, the cost of reunification has reduced what other funding sources, particularly the universities and the Ministry of Research, can afford. And 'baby boom' scientists, now qualified researchers wanting to set up their own projects, have swollen the pool.

Horst Kern, professor of cell biology at the University of Marberg and a member of the council's scientific advisory committee, says that the DFG is in a critical position. "For the first time we've reached the situation like that faced by the United States and some other European countries, where highly rated work is not funded."

For example, last autumn's meeting of the DFG approved 29 of 44 applications for the priority programme of grants, which fund large interdisciplinary projects and can be worth up to DM6 million. However, the council could afford to fund only 17 , and non-scientific criteria such as 'urgency' were brought into the final selection process. Official figures indicate that less than 45 per cent of grant applications in western Germany are now successful.

The council's major source of funding, the German Ministry of Science and Research (Bundesministerium für Forschung und Technologie), will respond to the request for increased funding after its own budget is set by the Minister of Finance in July. Negotiations are also continuing with individual states, which provide a quarter of the council's funding. 